RESEARCH ARTICLE - ANTS

\title{
Foraging behavior of leaf cutting ants: How do workers search for their food?
}

\author{
RV TRAVAGLINI, LC FORTI, RS CAMARGO
}

Universidade Estadual Paulista - UNESP, Botucatu, SP, Brazil

\author{
Article History

\section{Edited by} \\ Evandro do Nascimento Silva, UEFS, Brazil \\ Received 24 November 2014 \\ Initial acceptance 19 February 2015 \\ Final acceptance 11 March 2015

\section{Keywords} \\ leaf cutting ants, foraging, Atta sexdens \\ rubropilosa.

\section{Corresponding author \\ Roberto da Silva Camargo \\ Laboratório de Insetos Sociais-Praga \\ Departamento de Produção Vegetal \\ Faculdade de Ciências Agronômicas \\ Universidade Estadual Paulista (UNESP) \\ Caixa Postal 237, 18603-970 \\ Botucatu- SP, Brazil \\ E-Mail: camargobotucatu@yahoo.com.br}

\begin{abstract}
Foraging behavior of leaf cutting ants: How do workers search for their food? Forager ants search for adequate food sources in nature and, after their discovery, they decide whether the source is suitable or not for the colony. However, we asked "How do workers seek out the substrate for cultivation of the symbiontic fungus on which they feed? To answer this question, we evaluated the distance traveled by individual workers in the search of food and the distance traveled to return to the nest, as well as the time and velocity necessary for these activities. The results showed that the distance traveled by the leaf cutting ant, Atta sexdens rubropilosa (Linneus, 1758), in the search of food was greater than the distance traveled to return with the substrate to the colony. On the other hand, the mean time and velocity were similar for food search and return to the colony. These results support the hypothesis of information transfer, according to which the worker needs to return to the nest at the beginning of foraging to transfer information to other workers and thus to establish the process of worker ant foraging. It can be concluded that workers travel large distances in a random manner until finding their substrate, but the return to the nest is efficient considering the shorter distance traveled.
\end{abstract}

\section{Introduction}

Leaf cutting ants present a notable division of labor during foraging and cultivation of the symbiontic fungus, generating food resources for the colony (Hölldobler \& Wilson, 1990). For this purpose, workers need to select and forage a large number of plant species (Rockwood, 1976). Foraging depends on the size, density of quality of the available food source (Traniello, 1989). Selection, which is an important foraging step, is related to the content of nutrients and secondary compounds of plant species and to the physical resistance to cutting (Cherrett \& Seaforth, 1970; Rockwood, 1975; Waller, 1982; Cherrett, 1972; Nichols-Orians \& Schultz, 1990; Roces \& Hölldobler, 1994; Tautz et al., 1995). However, until finding an adequate plant species, the scout worker needs to search for it in the environment where it is located. Once the scout worker has found a food source, the loaded forager returns to the nest, communicating the location and quality of the discovery to the nest mates (Therien, 1988;
Roces, 1994, 2002; Lopes et al., 2004). The recruited workers are conditioned to the odor of the food fragment carried by the scout worker and the learned odor is then used as a clue at the time of decision-making about which plant to collect, as demonstrated experimentally in Acromyrmex lundi (Roces, 1990, 1994; Lopes et al., 2004, Bollazzi \& Roces, 2011).

Obviously, the establishment of mass recruitment requires an increase in the deposition of pheromone along the trail, leading workers to participate in the demarcation and maintenance of chemical trails (Jaffé \& Deneubourg, 1992). This recruitment is influenced directly by the scout worker, but the decision making process is also affected by interactions between workers (De Biseau \& Pasteels, 2000; Roces, 2002). Furthermore, the previous experience of workers also influences the selection of plants during foraging (Fowler, 1982; Howard et al., 1996; Camargo et al., 2003).

Since scout workers are responsible for seeking out the adequate plant and for recruiting nest mates, we asked "How do workers seek out the substrate for cultivation of the symbiontic fungus on which they feed?" To answer this 
question, we evaluated the distance traveled by individual workers in the search of food and the distance traveled to return to the nest, as well as the time and velocity necessary for these activities.

\section{Material and methods}

Three Atta sexdens rubropilosa colonies, maintained in the Laboratory of Social Insects, LISP, UNESP, Botucatu, were used. Each colony consisted of an acrylic box $(500 \mathrm{~mL})$ containing the fungus garden connected to two containers that served as a feeder and waste deposit by the ants. The colonies were fed Acalypha spp. and Ligustrum spp. and were maintained at a temperature of $24 \pm 2{ }^{\circ} \mathrm{C}$ and relative humidity of $80 \%$ under a 12 -h light period.

An apparatus resembling a table was constructed to permit the observation of the behavior of foragers. The table, which is illustrated in Figure 1, had stainless steel legs and a glass base $(95 \times 210 \mathrm{~cm})$ delimited by glass borders containing Fluon and was elevated $1.5 \mathrm{~m}$ above the floor.

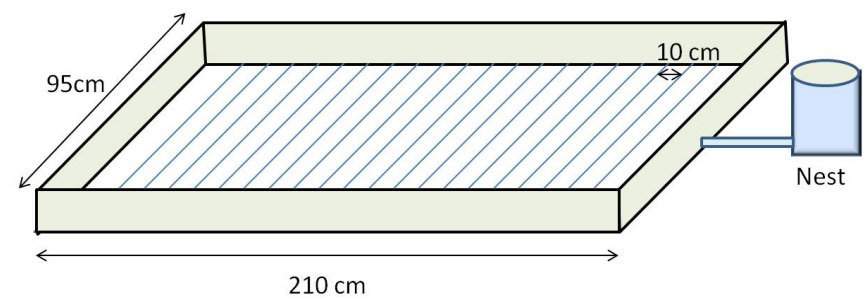

Fig 1. Schematic drawing of the observation apparatus. The observer is positioned beneath the apparatus.

The colony was connected to one end of the table and remained without food on the day prior to the experiment. The food source (leaves of the preferred plant species such as Acalypha wilkesiana, Gmelina arborea and Ligustrum japonicum) was placed on the opposite end. After release of the ants, the pathway of the individual until finding the food source and their return to the nest were observed. Fifteen releases were performed per colony, for a total of 45 releases. The trajectory of this scout worker was recorded on the lower surface of the glass with a marker pen and measured with an analog curvimeter, which provided measures of the distance traveled. The time of displacement was recorded with a chronometer to calculate the mean velocity. The following parameters were evaluated: total foraging trip duration of the individuals, total distance traveled, and mean velocity. The data were analyzed by the paired t-test $(\alpha=0.05)$ using the BioEstat 5.0 program.

\section{Results}

The mean distance traveled in the search of food was greater than the distance traveled during return with the food to the colony $(4.3 \pm 2.2$ versus $1.3 \pm 0.5 \mathrm{~m})$, with the difference being statistically significant $(t=8.9491$, d.f. $=88, \mathrm{p}<0.0001)$.
The total time necessary for the foraging of leaves was greater in the first release and decreased during subsequent releases. The longest time observed was $4 \mathrm{~h}$ and $23 \mathrm{~min}$ and the shortest time was $19 \mathrm{~min}$. The mean time necessary for scout workers to find the leaves in the center of the table was $441 \pm$ 313.10 seconds in the presence of leaves and $469 \pm 322.84$ in their absence, with no significant difference between times $(\mathrm{t}$ $=-0.4147$; d.f. $=88 ; \mathrm{p}=0.6794)$.

The mean velocity was $0.585 \pm 0.35 \mathrm{~m} / \mathrm{min}$ during food search and $0.606 \pm 0.23 \mathrm{~m} / \mathrm{min}$ during leaf transport. This difference was not statistically significant $(\mathrm{t}=1.6697$; d.f. $=88 ; \mathrm{p}=0.0989)$.

\section{Discussion}

Forager ants search for adequate food sources in nature and, after their discovery, decide whether the source is suitable or not for the colony. This acceptance depends on the physical and chemical characteristics of the plants (Howard, 1987) and on the previous experience of the workers (Saverschek et al., 2010). If the food source is adequate, the workers return to the nest (with or without load), depositing a chemical trail and interacting with nest mates along the trail and/or inside the nest (Roces, 1990; Roces, 1993; Jaffé \& Howse, 1979). However, it remains unknown how workers search for food sources in space and, once discovered, how they return to the nest.

The present results showed that workers travel a large distance until finding a food source, but the distance is shorter when returning to the nest. This behavior of the first foragers agrees with the observation of Bollazzi and Roces (2011) that this faster return to the nest is related to the communication of information about food to workers residing inside the nest, which actively stimulates foraging. This foraging characteristic is supported by the hypothesis of information transfer (Núñez, 1982; Roces \& Núñez, 1993; Roces \& Bollazzi, 2009), an adaptive advantage of leaf cutting ants which permits to rapidly monopolize a newly discovered source at an early stage (Roces \& Hölldobler, 1994). The foraging period is limited by environmental variables (Lewis et al., 1974) and by neighborhood competition for the same food source (Whitehouse \& Jaffé, 1996).

Interestingly, the time of travel for food search and return to the colony by scout workers was similar despite the difference in the distance traveled. This finding is due to the fact that, at the time of return, workers deposit venom gland secretions to indicate the rapid transport of these leaves to the nest, establishing chemical trails so that the other workers can find the food source (Vilela \& Della Lucia, 1987). The mean velocity of substrate search and leaf transport to the nest was similar $(0.585$ and $0.606 \mathrm{~m} / \mathrm{min}$, respectively). These values agree with those reported by Schlindwein (1996) who found a maximum velocity of $1.57 \mathrm{~m} / \mathrm{min}$ and a minimum velocity of $0.571 \mathrm{~m} / \mathrm{min}$. Usually, $68.8 \%$ of workers travel at a velocity of 0.5 to $1.0 \mathrm{~m} / \mathrm{min}$ (Gomides, 1997). In A. cephalotes, the velocities are higher, $1 \mathrm{~m} / \mathrm{min}$ for loaded individuals and $2 \mathrm{~m} /$ 
min for unloaded individuals (Lewis et al., 1974). However, this velocity is directly affected by environmental factors, such as the distance between the nest and food source, foraging trail gradient, and roughness of the substrate through which the workers pass (Ribeiro, 2013).

In summary, the distance traveled during substrate search is greater than the distance traveled during return with or without load. However, we observed a similar time and mean velocity for food search and return to the nest in the leaf cutting ant, Atta sexdens rubropilosa. These results corroborate the hypothesis of information transfer (Núñez, 1982; Roces \& Núñez, 1993; Roces \& Bollazzi, 2009), according to which the worker needs to return to the nest at the beginning of foraging to transfer information to other workers (Bollazzi \& Roces, 2011). It can be concluded that workers travel large distances in a random manner until finding their substrate, but the return to the nest is efficient considering the shorter distance traveled.

\section{References}

Bollazzi, M. \& Roces, F. (2011). Information needs at the beginning of foraging: grass-cutting ants trade off load size for a faster return to the nest. PLoS ONE, 6(3): e17667.

Camargo, R.S., Forti,L.C., Matos, C.A.,Lopes, J.F., A.P.P., Ramos, V.M. (2003). Post-selection and return of foraged material by Acromyrmex subterraneus brunneus (Hymenoptera: Formicidae). Sociobiology, 42: 93-102.

Cherrett, J. M. (1972). Some factors involved in the selection of vegetable substrate by Atta cephalotes (L.) (Hymenoptera: Formicidae) in tropical rain forest. Journal of Animal Ecology 41: 647-660.

Cherrett, J.M. \& Seaforth, C.E. (1970) Phytochemical arrestants for the leaf-cutting ants, Atta cephalotes (L.) and Acromyrmex octospinosus (Reich), with some notes on the ants' response. Bulletin of Entomological Research, 59: 615-625.

De Biseu, J.C. \& Pasteels, J. M. (2000). Response thresholds to recruitment signals and the regulation of foraging intensity in the ant Myrmica sabuleti (Hymenoptera, Formicidae). Behavioural Processes, 48: 137-148.

Fowler, H. G., Forti, L. C., Brandão, C. R. F., Delabie, J. H. C., Vasconcelos, H. L. (1990). Ecologia nutricional de formigas. In: Panizzi, A. R., Parra, J. R. P. Ecologia nutricional de insetos e suas implicações no manejo de pragas. Editora Manole.

Fowler, H. G. (1982). Habitat affect in fungal substrate selection by a leaf-cutting ants. The New York Entomological Society Journal, 90: 64-69.

Gomides, C.H.F., Della Lucia, T.M.C., Araújo, F.S., Moreira, D.D.O. (1997). Velocidad de forrajeo y área foliar transportada por la hormiga Acromyrmex subterraneus (Hymenoptera: Formicidae). Revista de Biologia Tropical, 45: 1663-1667.
Hölldobler, B. \& Wilson, E.O. (1990). The ants. Harvard University Press, Cambridge, 746 p.

Howard, J. J., Henneman, M. L, Cronin, G., Fox, J.A., Hormiga, G. (1996). Conditioning of scouts and recruits during foraging by a leaf-cutting ant, Atta colombica. Animal Behaviour, 52: 299-306.

Howard, J.J. (1987). Leaf-cutting ant diet selection: the role of nutrients, water, and secondary chemistry. Ecology, 68: 503-515.

Jaffe, K. \& Deneubourg, J.L. (1992). On foraging, recruitment systems and optimum number of scouts in eusocial colonies. Insectes Sociaux, 39: 201-213.

Jaffé, K. \& Howse, P.E. (1979). The mass recruitment system of the leaf cutting ant, Atta cephalotes (L.). Animal Behaviour, 27: 930-939.

Lewis, T., Pollard, G.V. \& Dibley, G.C. (1974). Rhythmic foraging in the leaf-cutting ant Atta cephalotes (L.) (Formicidae: Attini). Journal of Animal Ecology, 43: 129-141.

Lopes, J.F., Forti, L.C. \& Camargo, R.S. (2004). The influence of the scout upon the decision making process of recruited worker in three Acromyrmex species (Formicidae: Attini). Behavioural Processes, 67: 471-476.

Nichols-Orians, C.M. \& Schultz, J.C. (1990). Interactions among leaf toughness, chemistry, and harvesting by attine ants. Ecological Entomology 15: 311-320.

Núñez, J.A. (1982). Honeybee foraging strategies at a food source in relation to its distance from the hive and the rate of sugar flow. Journal of Apicultural Research, 21: 139-150.

Ribeiro, L.F. (2013). Modulação e organização do forrageamento em Acromyrmex subterraneus mollestans Santschi 1925. Universidade Federal de Juiz de Fora, Pós- Graduação em Ciências Biológicas, Mestrado em Comportamento e Biologia Animal.

Roces, F. (1990). Olfactory conditioning during the recruitment process in a leaf cutting ant. Oecologia, 83: 261-262.

Roces, F. (1993). Both evaluation of resource quality and speed of recruited leaf cutting ants (Acromyrmex lundi) depend on their motivational state. Behavioral Ecology and Sociobiology, 33: 83-189.

Roces, F. \& Bollazzi, M. (2009). Information transfer and the organization of foraging in grass- and leaf-cutting ants. In: Jarau S, Hrncir M, eds. Food Exploitation by Social Insects: Ecological, Behavioral, and Theoretical Approaches. CRC Press: Contemporary Topics in Entomology Series. pp 261-275.

Roces, F. \& Hölldobler, B. (1994). Leaf density and a tradeoff between load-size selection and recruitment behavior in the ant Atta cephalotes. Oecologia, 97: 1-8.

Roces, F. \& Núñez, J.A. (1993). Information about food quality influences load-size selection in recruited leaf-cutting ants. Animal Behaviour, 45: 135-143.

Roces, F. (2002). Individual complexity and self-organization in foraging by leaf-cutting ants. Biological Bulletin, 202: 306-313. 
Roces, F. \& Hölldobler, B. (1994). Leaf density and a tradeoff between load-size selection and recruitment behavior in Atta cephalotes. Oecologia, 97: 1-8.

Rockwood, L.L. (1975). The effects of seasonality on foraging in two species of leaf-cutting ants (Atta) in Guanacaste Province Costa Rica. Biotropica, 7: 176-193.

Rockwood, L.L. (1976). Plant selection and foraging patterns in two species of leaf-cutting ants (Atta). Ecology, 57: 48-61.

Saverschek ,N., Herz, H., Wagner, M. \& Roces, F. (2010). Avoiding plants unsuitable for the symbiotic fungus: learning and long-term memory in leaf-cutting ants. Animal Behaviour, 79: 689-698.

Schlindwein, M.N. (1996). Avaliação das estratégias de forrageamento de Atta sexdens rubropilosa Forel, 1908 (Hymenoptera: Formicidae) com o uso de manipulação espaço - temporal de recursos vegetais. Rio Claro: UNESP. Tese de Doutorado em Ciências Biológicas.

Tautz, J., Roces, F. \& Hölldobler, B. (1995). Use of a soundbased vibratome by leaf-cutting ants. Science, 267: 84-87.
Therrien, P. (1988). Individual food choices by foragers from the species Acromyrmex octospinosus (Reich), the leaf cutting ant. Memoirs of the Entomological Society of Canada, 146: 123-130.

Traniello, J.F. (1989). Foraging strategies of ants. Annual Review of Entomology, 34: 191- 210.

Vilela, E.F. \& Della Lucia, T.M.C. (1987). Feromônios de Insetos-Biologia, Quimica e Emprego no Manejo de Pragas. Viçosa, Imprensa Universitária da Univ. Federal de Viçosa.

Vilela, E.F. \& Howse, P.E. (1986).Territoriality in leafcutting ants, Atta spp. In.: Lofgren, C.S.; Vander Meer, R.K. Fire ants and leaf-cutting ants: biology and management, Westview: Boulder, p. 159-171,

Waller, D.A. (1982). Leaf-cutting ants and avoided plants: defences against Atta texana attack. Oecologia 52: 400- 403.

Whitehouse M.E.A \& Jaffé K. (1996) Ant wars: combat strategies, territory and nest defence in the leaf-cutting ant Atta laevigata. Animal Behaviour, 51: 1207-1217. 